\title{
LANGUAGE TEACHING METHODS FOR TUTORS' PREPARATION IN THE FIRST HALF OF THE XX CENTURY
}

The article deals with the processes between cultural integration at the national and international levels which have led to the modernization of the content and methodological support of the educational sector, and have actualized the issues of qualitative updating of the pedagogical training of teachers of philological subjects.

Professional pedagogical and language training of teachers in modern innovative programs (National Doctrine of Educational Development, Integrated Teacher Program, etc.) should ensure the transition to advance educational development, its humanistic orientation and holistic understanding of the socio-cultural phenomenon of being a country. Important is the problem of improving the cultural, linguistic training of teachers in view of the growing need for communication and cooperation between countries.

Analysis of a wide range of historical and pedagogical works confirmed that the problem of vocational training of philological teachers in higher educational establishments of Ukraine in the first half of the twentieth century was not directly investigated. Today, the profession-pedagogical field addresses a number of issues, in particular:

- study of socially contradicted contradictions that became the driving force for the development of language and practicalmethodological pedagogical training of teachers-philologists in higher educational establishments of Ukraine during the formation of the national system of pedagogical education - the first half of the twentieth century;

- determination of the peculiarities of teachers' preparation for teaching philological subjects in the context of the culturalnational movement in Ukraine in the specified historical period;

- generalization of the experience of organization of philological education of teachers in higher educational institutions of Ukraine of the studied period.

It can be said that the Kharkov Pedagogical Institute of Foreign Languages, which had a serious material base, made many different efforts to increase the level of training of foreign language teachers by the efforts of all teaching staff. Thus, in the 30's of the twentieth century meaningful experience of foreign language teacher training and experience in using scientific approaches to develop language teaching techniques.

Key words: military and physical education disciplines, teacher-philologists, pedagogical institutes, literary faculties, pedagogy, methodical conferences, syntax, phonetics, semantization.

\section{(статтю подано мовою орихіналу)}

The objective of the study is the training of philological teachers in the first half of the twentieth century, including foreign language teachers, which was often discussed at the meetings of the People's Commissar. A number of measures have been taken to reform curricula for pedagogical institutes. In particular, the cycle of socio-economic disciplines by volume was reduced to $10 \%$ of the total number of hours of the curriculum. Out of 37 disciplines, 20-22 were formed. It was emphasized that the curricula of higher education institutions should be individualized, taking into account the type of schools for which they were preparing teachers. The ratio of theory and practice was set at 1: 1. The transition from the lecture system to active teaching methods should be taken into account in the curriculum. Significantly, the new curriculum envisaged a continuous week and a school year. It was emphasized that the content of the programs should correspond to a specific specialty. But most of the recommendations in the practice of training of philological teachers in higher educational establishments of Ukraine have not been implemented or partially implemented. Thus, the ratio of hourly load to socio-political and special disciplines is $72.3 \%$, pedagogical and pedagogical disciplines $-11.8 \%$, industrial practices $-5.5 \%$, military-physical education and foreign language $-10.4 \%[1]$.

In the 1930 's, as shown by the generalization of the practice of professional pedagogical education, philological teachers were trained at the faculties of literature of pedagogical institutes and industrial-pedagogical and agroindustrial institutes. Tables 2.7, 2.8 of Appendix B give an example of a curriculum for the public and literary department of the Agro-Pedagogical Institute.

As you can see, the structure of the curricula in a way took into account the recommendations of government decisions in 1930. To accomplish these tasks, all subjects were divided into six groups: social-political, pedagogical, special, polytechnic, physical, military and artistic.

The weight of specialized disciplines has increased in all types of educational institutions.

The syllabuses analyzed had the following positive aspects: clearly, in comparison with the previous plans, the training profile was defined; the goals of preparation of the teacher-cyclist (wide profile) are taken into account; pedagogical and industrial practice had up to $40 \%$ of study time; a program of physical and aesthetic education of students was envisaged; minimum polytechnic training.

The most serious disadvantages were: incorrect allocation of hours among the groups of disciplines (for example, $16 \%$ of the time of military and physical education disciplines was allocated for the group of the public-literary department, and $15 \%$ for pedagogical disciplines and teaching methods of four subjects); special subjects are not 
fully represented (only $22 \%$ ); literary studies would be advisable to study after studying the literature itself, etc. Specialization of Ukrainian and Russian languages was poorly expressed; there was no pedagogical practice [2].

Since 1936, the curricula of higher education institutions have been developed taking into account the following tasks: the transition from a broad profile to a narrow profile of teacher training; elimination of multiple subjects; introduction of special courses, special seminars and optional courses; strengthening the academic character of special training; qualitative improvement of the content of pedagogical disciplines; taking into account individual and differentiated approach.

This was marked by the expansion of the activity of pedagogical institutes, institutes of foreign languages. Analyzing the curricula of higher education institutions operating from 1941 to 1960 , the following features of their structure should be singled out: reduction of the total volume of educational load; increasing the number of hours for the study of special and pedagogical disciplines; clarification of profiles of pedagogical and professional training; increasing hours of teaching practice.

More than ten departments were working at Kharkiv Pedagogical Institute. Each of them developed a work plan for the semester that was discussed in detail at the meetings. This plan included work and individual plans, additional assignments of teachers to work with non-attending students, control over the course of academic work conducting certification at the department on the general schedule. The plan included preparation for sessions, participation in methodical conferences, and work with students, curricula and their implementation. For example, the plan of work of the Department of Translation for the 1947-1948 academic year was to organize the work of students in language classrooms with additional material, to hold six open lectures, to develop methodological recommendations for practical application in the educational process, to hear reports: "Selection of material for translation from hearing", "History of Translation in Ukraine", "Test Methods"; to make assignments for students of correspondence form of study.

At the beginning of each semester, teachers prepared individual plans, which included activities for study work: planning of consultations, lectures, practical classes, attending lectures and practical classes of other teachers, preparation of open lessons; on educational work: preparation of visual aids, reports. Teachers also made plans to improve pedagogical skills.

At the end of each academic year, the departments reported on their work. In the academic year 1947-1948, the Department of German Philology stated in the report that there were 12 people employed at the department, five members of the department participated in the development of the complex problem "Methods of teaching foreign languages in a special institution". Lecturer M. Goldstein worked on the topic "Methodology of introductory phonetic course". Lecturer P. Troyanovska made a report at the meeting of the department "Methods of fixing and correcting pronunciation", T. Pavlov "Types of visual examples and their use in teaching German". P. Richter and M. Brodskaya compiled a collection of dictations for the senior students of the German language faculty and prepared a report "Methods of Oral Speech Development in Senior Students". L. Roemer has compiled the vocabulary "Minimum for first year students". In order to ensure that students make fewer grammatical errors, they introduced a second-year practical morphology exam in the spring session. One and a half months before the session, there were organized daily alternations of the teachers of the department in the hostel. This gave students the opportunity to receive counseling on a daily basis. Consultants of laboratories and teachers were constantly consulted in foreign language offices. Teachers checked the home reading, held additional classes with students who did not catch up and excelled. On average, 10 to 12 people visit the office every day. Spelling and phonetic circles worked. The report also said that five pictures were purchased for oral language development, seven phonetic tables, and three grammar tables were developed. The cabinet hosted a phonetic competition and five evenings in a foreign language. The wall-paper was published monthly in a foreign language [3].

The Department of German Philology stated in its report that V. Shapiro - Senior Lecturer, Head of the Department, had a course in the history of German language and lexicology, A. Shehtman - a course in theoretical and practical grammar, E. Umanskaya - Senior Lecturer - a course in practical phonetics, in parallel at the department of German language the course of vocabulary, E. Shklyarevskaya - the course of scientific phonetics and practical grammar. E. Umanskaya prepared two textbooks for the academic year 1947-1948: "Syntax in German" (for parttime students), "Oral Speech Development Manual" (for students of the first year of special higher education). The first of these manuals was used in the case of part-time students.

Summarizing the experience of higher education showed that in order to supervise and assist students, the department kept a log of current success, which noted the daily work of students at seminars. Listening to the reports of the students-seniors of groups at the meetings of the department on work on theoretical disciplines was practiced followed by discussion of the identified shortcomings. The members of the department worked out the necessary materials for the examinations.

The department raised the question that the curriculum should include an examination in the theory of language at the end of the sixth semester, so that during the transition from the third to the fourth year, knowledge of theoretical disciplines should be taken into account.

The Department of History and Geography's report contained information about the department's composition. It consisted of the head, professor, doctor of technical sciences N. Pakul and three associate professors: T. Skobacandidate of historical sciences, G. Friesman - candidate of historical sciences and G. Padalka - candidate of geo- 
graphical sciences. The teaching work of the department consisted of the following sections: lectures on the history of individual countries (England, France and Germany at the respective faculties), provided by Professor N. Pakul, who read the period of the Middle Ages and the beginning of modern times until the second half of the eighteenth century., Associate Professor T. Skoba who read new and recent history; course of lectures and practical classes on geography of individual countries (read by G. Padalka); courses in the history of diplomacy (read by G. Friesman); course in international relations (read by T. Skoba). The department supervised coursework.

The quality of conducting classes by teachers from the heads of departments, deans and management of the institution was conducted. They supervised the attendance of the lectures, followed by a discussion with the teachers and discussion of the lectures at the meetings of the departments, reviewing the lectures and practical classes. Conducted a preliminary discussion of lecture notes at a meeting of the chairs before reading it in the audience; there were periodic reviews of the departments with the obligatory attendance of lectures by commissions appointed by the director of the institute.

Departments on each topic prepared methodical developments, which were previously discussed and approved by cycle commissions. This greatly helped the young teachers. For them it was practiced reading lectures on the history of language, grammar, lexicology, consulting in phonetics. Lecturers and consultants were trained and experienced teachers. Joint meetings of related departments were practiced [4].

In order to successfully master the profession of teacher at the Institute were used different methods, which in the 30's of the twentieth century testified about the pedagogization of the educational process, which was intended to achieve the goal: to prepare highly qualified teachers for the school. In order for a student to become a teacher, he or she must be equipped not only with knowledge but also with the ability to pass on their knowledge to the younger generation. Practically pedagogization was implemented in this way. During the lectures, students were taught the basic requirements of the teacher. Teachers of a particular subject had to have a thorough theoretical knowledge and be able to apply interesting and useful teaching methods, because in the beginning of their work the young teacher adheres to the methods used by the teacher with whom this young teacher studied. For example, during the organizational phase of a lesson, the teacher had to require that all students welcome him/her as he/she was present, because this rule existed and exists at school; clearly call students to get used to where the lesson begins. During the homework test, the teacher had to teach the students on problem material to observe and analyze the mistakes of their classmates. This pursued two goals: a) to teach students not to miss students' mistakes; b) to develop oral language skills because errors were analyzed in a foreign language.

For reading the text, one could choose materials from the school textbooks for the upper classes to familiarize the students with the school texts. After reading the text, students were asked to ask the audience, or vice versa, the audience. The teacher should also provide appropriate methodological guidance. Students were taught not to stand with their backs to class while writing words on the blackboard and were taught to write neatly and beautifully. The teacher gave the presentation of new material clearly, clearly, illustrating with examples. During consolidation of the material students developed agility, ability to quickly navigate, offered a number of examples of a rule. Allowed third- and fourth-year students to take lessons for 20-25 minutes themselves under the guidance of the teacher. Tried to report homework a few minutes before the end of the class, and then required its completion.

Professional training of students began with the first year. Initially, conversations were conducted on relevant topics. Further, teachers required the students to have the following skills: 1) speak loudly, slowly, clearly; 2) write clearly, beautifully, in capital letters; 3 ) be able to separate the main from the minor; 4) not to stand back to the audience, conducting any analysis at the board; 5) to ask the question first and then give the name. At the same time, teachers demonstrated the need to meet these requirements in the classes they conducted.

In grammar classes, students were advised that it was expedient to use the material learned in high school in high school, that grammar could not be studied as a separate subject; it should be linked to vocabulary.

In the vocabulary classes, the teacher stated what vocabulary the students needed and how to introduce new words, that is, how to conduct semantization of words. In the first year students were introduced to school textbooks. In the senior year students gave lessons in vocabulary classes (2-3 lessons per semester). These lessons were discussed immediately. Similar work was done in phonetics classes.

The necessity of conducting such classes required coordination, first of all, with the department of methodology, because at seminars on methodology students also gave trial lessons and passed the program minimum of secondary school in vocabulary, grammar, phonetics, in order to prevent unnecessary duplication and with the teachers of the native language.

From the fourth semester, the work with school textbooks was supplemented by the analysis of didactic provisions of the textbook, for example: relevance of homework to the target instructions of this text, selection of vocabulary, frequency of use of vocabulary to be learned, with the following group discussion. Such work aroused interest of students, helped them to independently evaluate not only the given, but also any textbook on language. All this was necessarily connected with the pedagogical practice of students.

At the Kharkiv Pedagogical Institute of Foreign Languages in 1939, at the Faculty of English, French and German, with the qualification of a specialist teacher of secondary school with a term of study - four academic years, the specialty - English, German and French, the educational process was carried out according to the following 
plan: humanitarian and socio-economic training included political economy, history of Ukraine, general history, Ukrainian language, Latin, introduction to linguistics, world literature, Ukrainian literature, Russian summer atura, reading and interpretation of the authors. This cycle took 1655 hours. The cycle of vocational training was divided into two groups. The first group was called vocational training, which included the history of pedagogy, pedagogy, including school hygiene and psychology. This cycle took 250 hours. The second group was called professional-scientific subject preparation: literature of the learned language, history of the learned language, theory of the learned language, modern foreign language, methodology of teaching a foreign language. This cycle took 2270 hours. There was also a cycle of physical training with military training and physical education. This cycle took 300 hours. Classes were held in the form of lectures and practical classes.

In addition to compulsory classes, there were optional courses: practical classes were conducted in the first semester for 30 hours in the Ukrainian language. The history of philosophy was conducted in the fifth and sixth semesters of 60 hours. The history of the Ukrainian language took place in the third semester of 30 hours. The history of linguistic studies took place in the fourth and fifth semesters of 40 hours. The history of the language studied was conducted in the third and fourth semesters for 80 hours. Geography of the country - in the third semester 30 hours. The second foreign (modern) language was studied from the fourth to the seventh semester of 200 hours. The main language literature seminar was conducted in the sixth and seventh semesters for 60 hours. The main language literature workshop lasted 60 hours. Basic language history seminars were held in the seventh and eighth semesters for 40 hours. The history of aesthetic teachings was in the sixth semester of 30 hours. Schematic drawing lessons were held in the fifth semester of 20 hours. Voice production - in the sixth semester 30 hours. Educational psychology was in the seventh semester 40 hours. Special translation was conducted in the fifth, sixth and seventh semesters for 80 hours.

Political Economy Exams were conducted in the fifth and seventh semesters. Military training took the exam in the second semester. In psychology passed the exam in the first semester, in pedagogy - in the fourth, in the history of pedagogy - in the eighth, in Russian language exams were passed in the third and fourth semesters, from the entrance to linguistics, the exam was taken in the second semester, in the history of peoples of the SRS and in general history - in the third, in Russian literature - in the fifth. Latin was taken in the fourth semester and in the sixth - the exam. The second foreign language test was taken in the fifth semester and the exam was taken in the seventh. In the teaching of foreign languages, the exam was taken in the sixth semester. Modern foreign language was composed from the first semester to the seventh. In the seventh and eighth semesters the examinations of reading and interpretation of the authors were passed. In the sixth and eighth semesters passed the exam in the theory of language studied. The history of language was passed in the eighth semester and passed in the sixth. In the history of the language studied, the exams were in the sixth and eighth semesters. There were no exams for physical education; there were tests for physical education in the second and fourth semesters. From the world literature they took exams in the fifth semester, from the Ukrainian language in the second semester and in the first the credit. The Ukrainian literature was taken in the sixth semester.

In the summary data on the budget of time it can be seen that theoretical training in the first year took 42 six days, exam session 6 six days, vacations 12 weeks. In the second year, the theoretical training was held for 43 six days, the exam session for 5 six days, the holidays -12 weeks. In the third year, theoretical training lasted for 36 six days, a test session of 7 six days, a teaching practice of 5 six days and a 12-week vacation. In the fourth year theoretical training took 28 six days, exam session 6 six days, industrial practice - five six days and state exams 9 six days [5].

In the State Teachers' Institutes of 1939 at the faculties of foreign languages, with the qualification of a specialist - a teacher of foreign language 5-7 classes with a term of study, two academic years, specializing in English, French and German language, the educational process was carried out according to the following plan: cycle of humanities and socio-economic preparation took 591 hours. The cycle of vocational training - 150 hours. The cycle of professional and scientific subject preparation took 1458 hours. The cycle of physical preparation 120 hours. The teaching process took 2100 hours, 735 lectures and 1584 practical classes. In the first semester 660 hours, in the second -630 , in the third -616 , in the fourth -420 . There were five credits, in the first semester -3 , in the second -1 , in the third -1.180 consulting hours per group were spent for the whole term of study at the institute. In the first semester there were 22 six-day courses, in the second -21 , in the third -22 , in the fourth -15 . Optional disciplines were also held in teachers' institutes. Russian was in the first and second semesters for 80 hours. Seminar on Literature was held in the third and fourth semesters for 50 hours. General literature was conducted in the first and second semesters for 50 hours. Physical education was in the first and second semesters for 80 hours. Theoretical training was 43 six-year students in the first year, 37 students in the second year, the exam session lasted 5 six-days in the first year and 4 six days in the second year. Production practice was held in the second year of two six-days. The state exams were held in the second year of 5 six days. Vacations lasted 12 six days in the first and second courses. So, 60 and six students studied in the first and second courses. Pedagogical practice was conducted throughout the third semester for two hours on a six-day and two six-day days continuously in the fourth semester.

Conclusions. Summarizing the above, it can be argued that at different stages of the history of the training of philological teachers in domestic higher educational institutions the content of vocational training was peculiar. 


\section{Bibliography:}

1. Артемова Л. В. Педагогічна думка в другій половині XVIII - XIX ст. В. 1. Київ : Либідь, 2006. 360 с.

2. Бацевич Ф. С. Основи комунікативної лінгвістики. Київ : Академвидав, 2004. 344 с.

3. Бєляєв О. М. Концепція мовної освіти в Україні. Київ : Рідна школа, 1994. № 9. С. 71-73.

4. Бондар В. І. Стратегія і тактика стандартизації змісту й організації його засвоєння у процесі професійної підготовки вчителя на засадах компетентнісного підходу. Наукові записки : збірник наукових статей. Вип. 80. Київ : вид-во НПУ імені М. П. Драгоманова, 2009. С. 3-11.

5. Ушинський К. Д. Педагогічна спадщина в сучасній практиці виховання і навчання. Київ : Вища школа, 1980.96 с.

\section{References:}

1. Artemova L. V. (2006) Pedahohichna dumka v druhii polovyni XVIII - XIX st. / [Pedagogical thought in the second half of the XVIII - XIX centuries]. Kyiv: Lybid, 360 s. [in Ukrainian]

2. Batsevych F. S. (2004) Osnovy komunikatyvnoi linhvistyky. [Fundamentals of communicative linguistics]. - Kyiv: Academy. 342 s. [in Ukrainian].

3. Bieliaiev O. M. (1994) Kontseptsiia movnoi osvity v Ukraini [The concept of language education in Ukraine]. - K. : Ridna shkola. № 9. S. 71-73. [in Ukrainian]

4. Bondar V. I. (2009) Stratehiia i taktyka standartyzatsii zmistu y orhanizatsii yoho zasvoiennia u protsesi profesiinoi pidhotovky vchytelia na zasadakh kompetentnisnoho pidkhodu [Strategy and tactics of standardization of the content and the organization of its mastering in the course of professional training of the teacher on the basis of the competence approach] Naukovi zapysky: zb. nauk. statei. - K.: Vyd-vo NPU imeni M. P. Drahomanova. Vyp. 80. - S. 3-11. [in Ukrainian]

5. Ushynskyi K. D. (1980) Pedahohichna spadshchyna v suchasnii praktytsi vykhovannia i navchannia. [Pedagogical heritage in the modern practice of education and training]. - K.: Vyshcha shkola. - 96 s. [in Ukrainian]

Осьмачко С. А. Методи навчання мови для підготовки викладачів у першій половині ХХ ст.

Стаття розглядає процеси міжкультурної інтегращії на національному та міжнародному рівнях, які обумовили модернізацію змістовно-методичного забезпечення освітньої галузі, актуалізували питання якісного оновлення професійної педагогічної підготовки вчителів предметів філологічного спрямування.

Професійна педагогічна та мовна підготовка вчителів у сучасних інновачійних програмах (Національна доктрина розвитку освіти, комплексна програма “Вчитель” тощо) має забезпечити перехід до випереджувального розвитку освіти, ї̈ гуманістичну спрямованість та иілісне осмислення соиіокультурного феномена буття країни. Важливою є проблема поліпшення культурологічної, мовної підготовки вчителів у зв'язку зі зростаючою потребою спілкування та співпраці між краӥнами.

Аналіз широкого кола історико-педагогічних прачь підтвердив, щңо проблема професійної підготовки вчителівфілологів у вищих навчальних закладах Украӥни у першій половині ХХ ст. безпосередньо не досліджувалася. Сьогодення професійно-педагогічної галузі актуалізує иілу низку питань, зокрема:

- вивчення сочіально обумовлених протиріч, ще стали рушійною силою розвитку мовної та практико-методичної педагогічної підготовки вчителів-філологів у вищих навчальних закладах України у період становлення національної системи педагогічної освіти, а саме у першій половині ХХ ст.;

- визначення особливостей підготовки вчителів до викладання філологічних дисциплін в умовах культурноначіонального руху в Украӥні у зазначений історичний період;

- узагальнення досвіду організації філологічної освіти вчителів у вищих навчальних закладах України досліджуваного періоду.

У Харківському педагогічному інституті іноземних мов, який мав серйозну матеріальну базу, зусиллями всього викладаџького персоналу створювалось багато різноманітних заходів щңодо зростання рівня кваліфікації підготовки вчителів іноземних мов. Таким чином, у 30-ті рр. ХХ століття був накопичений змістовний досвід підготовки вчителів іноземних мов та досвід використання наукових підходів до розроблення методик викладання мов.

Ключові слова: воєнно-фізкультурні дисципліни, вчителі-філологи, педагогічні інститути, літературні факультети, педпрактика, методичні конферениії, синтаксис, фонетика, семантизація. 